\title{
DESCENTRALIZAÇÃO, FINANCIAMENTO E REGULAÇÃO: A REFORMA DO SISTEMA PÚBLICO DE SAÚDE NO BRASIL DURANTE A DÉCADA DE $1990^{1}$
}

\author{
Ricardo Cesar Rocha da Costa \\ Universidade Federal Fluminense
}

\begin{abstract}
RESUMO
Este artigo discute as politicas públicas no setor de saúde como parte da reforma do Estado brasileiro nos anos 90. A descentralização do Sistema Único de Saúde (SUS) e a busca de alternativas de financiamento diante de um cenário de crise econômica são os principais pontos da agenda desse periodo, no qual também destacou-se a força política adquirida pelo Ministério da Saúde a partir de 1998, na gestão de José Serra.

PALAVRAS-CHAVE: Ministério da Saúde; Sistema Único de Saúde; descentralização; financiamento; regulação; governo Fernando Henrique Cardoso; José Serra.
\end{abstract}

\section{INTRODUÇÃO}

A década de 1990 foi marcada pelo debate em torno da reforma do Estado no Brasil, tendo como pano de fundo o contexto da globalização financeira da economia e o aprofundamento da crise fiscal. No caso do setor da saúde pública, um outro fator relevante para a agenda de reformas foi o legado institucional deixado pela Constituição Federal de 1988, que determinou a instituição do Sistema Único de Saúde (SUS).

Este trabalho apresenta inicialmente um breve histórico da emergência e do desenvolvimento do sistema público de saúde no Brasil, com o objetivo de discutir as bases institucionais sobre as quais se efetuará o debate em torno da necessidade e da direção apontada pelas reformas do Estado nesse setor das políticas sociais.

A partir desse histórico, busca-se descrever e analisar as políticas públicas implementadas durante os anos 90, tendo como destaque as ações governamentais visando à descentralização do SUS

\footnotetext{
1 Este artigo é parte da Dissertação de Mestrado em Ciência Política Dilemas da reforma da saúde no Brasil frente à globalização financeira: implementando a descentralização do sistema público e a regulação do sistema privado de saúde (COSTA, 2000).
}

e as tentativas institucionais de viabilização financeira do sistema operadas durante o governo Fernando Henrique Cardoso (1995-2000). Em relação a esse último ponto, discute-se a polêmica em torno da criação, em 1997, da Contribuição Provisória sobre a Movimentação Financeira (CPMF), por ocasião da gestão de Adib Jatene como Ministro da Saúde, e a aprovação da Emenda Constitucional n. 29, em 2000, na gestão do Ministro José Serra. Defendo o argumento de que somente nesse último período (1998-2001) o Ministério da Saúde passou a constituir-se como uma força política de fato, conseguindo impor políticas públicas regulatórias que escapassem minimamente à orientação geral da administração Cardoso de priorizar a manutenção da estabilidade macroeconômica. Por fim, a atenção para esse setor das políticas sociais é entendida também como parte integrante da estratégia sucessória do governo para as eleições de 2002.

\section{ANTECEDENTES HISTÓRICOS: DA ERA VARGAS À NOVA REPÚBLICA}

As primeiras políticas médico-assistenciais surgiram como respostas do Estado à chamada questão social que, historicamente ignorada pelas nossas oligarquias, vem à tona de maneira fulminante nas décadas de 1910 e 1920. Dessa época é que temos a lei que obriga as empresas a instituir os seguros de acidentes de trabalho para os seus 
empregados (Decreto n. 3 724, de 1919), os grandes programas de saneamento e de controle de endemias no campo da saúde pública (Reforma Carlos Chagas, de 1923), assim como a constituição de um pioneiro "seguro social", com a criação das Caixas de Aposentadorias e Pensões (CAPs) (Lei Eloy Chaves, de 1923).

É importante frisar que, no conjunto dos países capitalistas, pelo menos até os anos 1930, havia uma participação modesta do Estado nas políticas voltadas para a saúde pública. As políticas então existentes eram voltadas para ações de saneamento básico e de combate a endemias (MEDICI, 1995, p. 104). No Brasil, as primeiras ações sanitárias organizadas ocorreram no final do século XIX, ainda durante o Império, com o objetivo de combater a febre amarela, causadora de grande mortalidade entre os imigrantes estrangeiros que serviam de mão-de-obra para a cafeicultura.

Com a Proclamação da República tem lugar uma incipiente política de saúde (TELAROLLI JR., 1996, p. 9). Já políticas de saneamento básico de alcance nacional somente viriam a ocorrer a partir da Revolução de $30^{2}$. Nesse período o Estado brasileiro passou a regulamentar e uniformizar a prática da assistência médica. Como se estendeu a prestação de serviços hospitalares aos associados das CAPs, a assistência médica passou a fazer parte do modelo da Previdência Social.

Durante o Estado Novo, com a constituição dos Institutos de Aposentadorias e Pensões (IAPs), esse modelo ganhou maior definição, tomando a forma de um seguro obtido a partir de uma contribuição suplementar. Impôs-se então, pela via autoritária, um modelo contratual, de previsibilidade atuarial, no qual a extensão dos benefícios estaria relacionada à capacidade financeira do indivíduo. Esse modelo não encara a prestação de serviços de assistência médica como um "direito universal", e opera através de segmentos profissionais construindo uma "cidadania regulada" (SANTOS, 1994), através da qual os

\footnotetext{
2 Um primeiro exemplo de ação institucional nesse sentido foi a criação, em 1942, no âmbito do Ministério da Saúde, dos Serviços Especiais de Saúde Pública (SESP). Estimulado pelo governo dos Estados Unidos, seu objetivo era o de "sanear o ambiente e assistir a população na zona da borracha, estratégica para o esforço de guerra dos Aliados” (BUSS, 1995, p. 75).
}

trabalhadores vinculados formalmente ao mercado de trabalho passariam a fazer jus a um rol de direitos a que os demais não teriam acesso.

A questão da unificação do sistema de Previdência, como alternativa ao sistema segmentado proveniente do Estado Novo, impôs-se como um tema de grande importância na pauta das reformas da República Populista. Essa unificação começou a desenhar-se com a aprovação da Lei Orgânica da Previdência Social (1960). O governo João Goulart ainda procurou encaminhar ao Congresso a proposta de criação de um fundo de assistência para os trabalhadores rurais em 1963, buscando a universalização da cobertura previdenciária (cf. MALLOY, 1986, p. 126-128). Contudo, a agenda de mudanças no setor da previdência somente foi promovida pelo regime militar. A sua não-implementação no período anterior deve ser creditada à conjuntura de instabilidade política, aliada a denúncias de insolvência financeira do sistema.

A criação do Instituto Nacional da Previdência Social (INPS), em 1966, em substituição aos antigos IAPs setoriais, representou a extensão dos benefícios da assistência médica aos trabalhadores formalmente empregados, vinculados pela Carteira de Trabalho e Previdência Social (CTPS). Tratavase ainda de uma herança da Era Vargas, de extensão da "cidadania regulada" pela via autoritária. Essa ampliação da cobertura viria logo depois trazer para o escopo da previdência os trabalhadores rurais através do FUNRURAL (1971), e também os empregados domésticos (1972) e os autônomos (1973).

O regime autoritário, portanto, encaminhava a reivindicação sindical no sentido da universalização da cobertura de atendimento médico por parte do Estado. Mas o fazia de uma forma extremamente centralizada, controlando rigidamente as políticas e os recursos, ao mesmo tempo que criava as condições institucionais para a emergência e o desenvolvimento de um sistema de saúde privado, como discutirei mais adiante. É dessa forma que adquire grande importância o Plano de Pronta Ação (PPA), de 1974. Ao articular, através da sistemática de convênios com a rede privada, todos os serviços de assistência médica existentes, o PPA correspondeu à "iniciativa mais expressiva de universalização da cobertura para a clientela não-segurada" (COSTA, 1996, p. 483), e também o financiamento do sistema privado pelos cofres públicos (CORDEIRO, 1984). 
Essa "opção privatista" consolidou-se com a criação, em 1975, do Fundo de Apoio ao Desenvolvimento Social (FAS), que chegou a destinar ao setor privado, em $1977,80 \%$ do valor dos financiamentos aprovados para a área da saúde (Braga e Góes de Paula apud FAVERET FILHO \& OLIVEIRA, 1990, p. 267). No início dos anos 80 , podia-se observar a estagnação da rede hospitalar pública, em detrimento da rede privada: a oferta de leitos e serviços nos hospitais privados passou a corresponder a $86 \%$ das admissões, contra $14 \%$ da rede pública. Cerca de $60 \%$ dos gastos do Instituto Nacional de Assistência Médica e Previdência Social (INAMPS) (que em 1978 substituíra o INPS), em 1981, foram direcionados para pagamento de hospitais e laboratórios privados.

Na segunda metade da década de 1970, consoante a rearticulação de setores organizados da sociedade civil contra o regime autoritário, entrou em cena um dos atores fundamentais no processo de universalização do acesso à assistência médica, pela via pública. Tratava-se do movimento sanitarista, encabeçado por um grupo de médicos sanitaristas reformistas, vinculados aos partidos de oposição ao regime militar, o Movimento Democrático Brasileiro (MDB) e ao na época ilegal Partido Comunista Brasileiro (PCB). O movimento sanitarista tinha como base de atuação os institutos de pesquisa universitários, em especial a Fundação Oswaldo Cruz e a revista Saúde em debate, do Centro Brasileiro de Estudos de Saúde (CEBES), fundado em 1976, com núcleos nas cidades do Rio de Janeiro, São Paulo, Belo Horizonte, Recife e Salvador (MELO, 1993; GERSCHMAN, 1995; ESCOREL, 1998). O movimento pretendia estabelecer um novo relacionamento entre o setor privado e o governo na área da saúde, retirando a área de saúde do Ministério da Previdência e Assistência Social (MPAS). Esse movimento de reforma, no sentido de universalização pública da cobertura de saúde, ocorria simultaneamente às propostas de entidades como a Organização Mundial de Saúde (OMS) e a Organização Pan-Americana de Saúde (OPAS), para que se desse maior atenção à saúde (MEDICI, 1995, p. 112).

Nos últimos anos do regime militar caíram significativamente os recursos para a saúde pública a ponto de o Banco Mundial mostrar uma redução de $41 \%$ nas despesas com saúde no Brasil entre 1978 e 1982 (cf. ABRANCHES, 1985, p. 72).
III. A NOVA REPÚBLICA E A LUTA PELA DESCENTRALIZAÇÃO DA SAÚDE PÚBLICA (1985-1994)

\section{1 O confronto de modelos na reforma do sistema de saúde}

Um documento do Banco Mundial, datado de 1987, apontava quatro políticas básicas visando à reforma dos sistemas de saúde dos países em desenvolvimento. Essas recomendações faziam parte de uma agenda mais ampla de políticas de ajuste econômico, recomendada aos países da América Latina pelas agências multilaterais. As sugestões de reforma na área da saúde compreendiam: a cobrança aos usuários dos serviços oferecidos pelo governo; o estímulo à utilização de planos privados de cobertura de riscos (a seguridade social ficaria exclusivamente para os pobres e os planos privados de pré-pagamento para os demais); a utilização mais eficiente de recursos governamentais (fim da corrupção, do desperdício, da má gestão dos recursos), e a descentralização dos serviços (Akin, Birdsall e De Ferranti apud POSSAS, 1995, p. 57).

Dentre as políticas citadas pelo Banco Mundial, a descentralização ganhou acentuado destaque, em virtude da convergência de interesses e orientações entre o tripé formado pelas instituições estrangeiras, os órgãos governamentais e o movimento sanitarista.

Medici aponta as razões que justificariam a opção dos programas de saúde pelas políticas de descentralização:

1. a possibilidade de redução dos gastos com saúde, que haviam crescido de maneira acentuada no Welfare State, com a progressiva ampliação dos beneficiários;

2. a tentativa dos Executivos centrais em deixar de se responsabilizar, numa conjuntura de crise econômica, pelos cortes ou aumentos dos gastos com saúde, buscando maior legitimidade para as decisões de governo relativas ao ajuste fiscal dos países;

3. os anseios dos movimentos sociais e poderes locais em responder pelas necessidades específicas das políticas de saúde de cada região;

4. a busca por novos arranjos na gestão dos sistemas de saúde que reduzissem o poder e o corporativismo dos sindicatos mais organizados; 
5. a possibilidade de flexibilização da "relação entre níveis de hierarquia dos serviços, consumo de tecnologia médica, gestão da saúde e prestadores públicos e privados", adequando o modelo às necessidades e condições de cada local (MEDICI, 1995, p. 105-106).

As políticas orientadas para a descentralização na área da saúde no Brasil compreenderam três fases distintas. A primeira iniciativa no sentido da descentralização da saúde pública aconteceu no final do regime militar, num contexto marcado pela recessão da economia. A implantação das Ações Integradas de Saúde (AIS), pelo Ministério da Previdência e Assistência Social em 1983, buscou aumentar a eficiência nas ações de saúde e a contenção dos custos da assistência médica sob a responsabilidade da previdência oficial. Para esse fim, criaram-se instâncias colegiadas que privilegiavam estados e municípios na programação e execução do orçamento da saúde. O governo procurou também legitimar as AIS, permitindo que delas participassem entidades representativas da sociedade civil (GIOVANELLA \& FLEURY, 1996, p. 180181; LEWIS \& MEDICI, 1998).

O passo seguinte para a descentralização remonta à Nova República. Durante o período de funcionamento do Congresso Constituinte, o Ministro da Previdência e Assistência Social, Raphael de Almeida Magalhães, criou o Sistema Unificado e Descentralizado de Saúde (SUDS) (Decreto n. 94 657, de 20 de julho de 1987). O SUDS iria transferir recursos aos estados e municípios que se propusessem a criar conselhos municipais ou estaduais de saúde e elaborassem planos municipais nessa área (MELO, 1993, p. 133). Essa segunda etapa da descentralização foi marcada pelo fechamento dos escritórios regionais do INAMPS, com a transferência das suas atribuições para as Secretarias Estaduais de Saúde (LEWIS \& MEDICI, 1998).

A descentralização de recursos promovida pelo SUDS encontrou contudo uma forte oposição, vinda dos grupos médico-empresariais, da burocracia central do Instituto INAMPS e da base parlamentar do Partido da Frente Liberal (PFL). Os grupos médico-empresariais sentiram-se prejudicados frente à possibilidade de redução dos recursos públicos repassados à saúde. Burocratas do INAMPS viram-se ameaçados de perder poder decisório, já que o órgão assumiria apenas as funções de controle e co-financiamento do sistema. Além disso poderiam perder seus escritórios regionais. O PFL agregou-se aos descontentes em razão da sua derrota nas eleições de 1986 e por perceber o SUDS como parte da estratégia de fortalecimento político da ala mais progressista do PMDB. Esta ameaçava atacar parte da base eleitoral pefelista vinculada a mecanismos de patronagem relacionados à transferência de verbas federais para a área da saúde (MELO, 1993, p. 134-135).

Além desse conflito de interesses dentro da base de sustentação partidária da Nova República - a Aliança Democrática, formada pelo PMDB e pelo PFL -, o governo Sarney vivia um período de isolamento político, decorrente da impopularidade vinda do fracasso do Plano Cruzado após o período eleitoral de 1986. A associação desses fatos acabou levando a uma reforma ministerial que afastou o Ministro da Previdência Social e o Presidente do INAMPS.

A correlação de forças dada por essa nova conjuntura implicou a inviabilização do SUDS: "A trajetória subseqüente do SUDS reflete a falta de compromisso e mesmo o boicote dos novos dirigentes à sua implementação. A mais significativa iniciativa da Nova República na área social resultou em paralisia decisória e fragmentação institucional" (MELO, 1993, p. 135).

É interessante observar o veto ao SUDS, uma vez que a descentralização já fôra apontada como meta do Executivo, que assim incorporava muitas das reivindicações do movimento sanitarista, sistematizadas durante a VIII Conferência Nacional de Saúde, realizada em Brasília, de 17 a 21 de março de 1986. Ali o SUDS fôra amplamente criticado por setores da área de saúde mais à esquerda, que o entenderam como uma forma de sobrevivência política do Ministério da Previdência e Assistência Social numa conjuntura de mudanças que incluía a convocação de uma Assembléia Constituinte. Esse era o entendimento do médico sanitarista e Deputado Federal Sérgio Arouca (PCB-RJ): “[...] o SUDS foi um projeto de começar a descentralizar, antes que a Constituinte previsse um projeto de reforma administrativa. Era uma forma de ainda sobreviverem no poder. Como eles sabiam que o modelo de previdência, tal como estava, não tinha saída, e que este caminharia para o Sistema Único, eles lutam por uma reforma por dentro, numa tentativa de modernização do INAMPS, já com a descentralização e a municipalização" (Arouca apud PEREIRA, 1996, p. 441). 
Outros atores políticos, como o ex-Ministro da Saúde Carlos Santana, expuseram também suas críticas ao SUDS, visto como um "desvio do caminho do SUS", tendo sido marcado pela "estadualização" e não por uma efetiva municipalização dos recursos. Por outro lado, diversos governos estaduais resistiram fortemente a assinar os convênios para a implantação do sistema. Uma das alegações mais fortes era gerada pela desconfiança dos secretários de Saúde de que os governos estaduais assumiriam encargos e depois não receberiam os devidos recursos que possibilitassem o atendimento (PEREIRA, 1996, p. 440-442).

Todos esses fatores contribuíram para o fracasso do SUDS. Mas a promulgação de uma nova Constituição, em 1988, daria seqüência ao processo de descentralização iniciado pelas AIS e pelo SUDS, transferindo a responsabilidade pública dos cuidados com a saúde para o âmbito dos municípios.

\section{III.2 A Constituição de 1988 e a definição de uma nova política de saúde pública - o SUS}

A Carta de 1988 estabeleceu o novo modelo da política de saúde no Brasil. Ao separar definitivamente as áreas de saúde e de previdência, a nova Constituição promoveu uma ruptura com o modelo criado durante a Era Vargas, que atribuía ao Ministério da Saúde a responsabilidade pelo combate às epidemias e tornava a assistência médica uma atribuição das instituições previdenciárias, segmentadas por categorias profissionais. A reforma instituída pelo regime militar pôs fim à segmentação, mas não significou mudanças de fundo nesse modelo. A partir de 1988, no entanto, a Previdência Social perdeu as atribuições relativas ao atendimento médico-hospitalar, passando a restringir-se à concessão e ao gerenciamento das aposentadorias, pensões e seguros de acidentes de trabalho.

A terceira fase das políticas orientadas para a descentralização foi definida nos artigos 196 a 200 da Constituição, que estabeleceram a criação do Sistema Único de Saúde (SUS). Segundo Medici (1995, p. 124-125), o SUS apresenta três inovações relevantes na política de saúde:

1. a definição de um comando único para o sistema de saúde em cada esfera de governo, o que implicaria a futura transferência do INAMPS para o Ministério da Saúde e a sua posterior extinção;
2. a descentralização como princípio organizador básico, cabendo aos estados e municípios a primazia da prestação dos serviços de saúde, e

3. a co-responsabilidade do financiamento dos recursos entre União, estados e municípios.

Há contudo quem negue a existência de mudanças no curso da política de saúde pública. De acordo com Nilson do Rosário Costa, a nova Constituição "pode ser considerada como uma síntese dos arranjos consolidados inercialmente ao longo das décadas de 1970/1980. As inovações conceituais e organizatórias que apareceram na Carta não expressavam nenhuma ruptura com quaisquer dos interesses que incidiram sobre a arena setorial nessas décadas" (COSTA, 1996, p. 496).

Uma definição importante da Constituição diz respeito ao direito universal à saúde, o qual, agregado ao direito à assistência social e à previdência, vai implicar o direito mais geral à seguridade social. Os recursos para essa nova área seguridade social - têm como base financiamentos vindos da Previdência Social, do Finsocial-Cofins e da Contribuição sobre o Lucro Líquido de Pessoas Jurídicas, entre outros impostos e taxas.

O Artigo 199 da Constituição define o SUS como um sistema organizado em rede, envolvendo participação social, segundo o princípio descentralizador e cooperativo. A legislação complemen$\operatorname{tar}$ (Lei n. 8 142, de 1990) prevê a implementação de um processo decisório amplo, com a instituição dos conselhos de saúde em cada esfera de governo, atuando de maneira integrada (COSTA, 1996, p. 497).

Por outro lado, a Lei n. 8.080, do mesmo ano, reconheceu a necessidade de funcionamento de um sistema privado de saúde, o qual ficou restrito às empresas de capital nacional, uma vez que ficou vetada a entrada de empresas estrangeiras nessa área (COSTA, 1996, p. 497).

A inclusão do SUS na Constituição Federal representou a vitória das teses aprovadas na VIII Conferência Nacional de Saúde de 1986. Ela foi apoiada pela aliança entre os partidos com um perfil progressista (PMDB, PSDB, PT, PDT, PCB e PCdoB) no Congresso, aos quais se uniram o movimento sindical e alguns movimentos populares (como, por exemplo, o Plenário Pró-Participação Popular na Constituinte). Essa aliança conseguiu fazer frente aos setores mais conservadores do 
PMDB, PTB, PDS e PFL, que, organizados em torno do "Centrão", defendiam os interesses do lobby organizado pelo setor privado de saúde. Segundo o depoimento do médico e Deputado petista Eduardo Jorge, dois fatores teriam contribuído para a vitória inicial do movimento sanitário na Constituinte:

1. o fato de esse movimento, ao contrário do setor privado, ter iniciado o processo constituinte com uma proposta já consolidada, e

2. a opção por parte dos setores conservadores em priorizar a discussão temática das questões relativas à ordem econômica, permitindo que um arco de alianças envolvendo o centro e a esquerda dominasse a composição das comissões e subcomissões da área social (PEREIRA, 1996, p. 446447).

O texto final da Constituição de 1988, no entanto, permitiu a recomposição do setor privado em torno da manutenção dos seus interesses. Duas importantes alterações foram promovidas em dois artigos do anteprojeto apresentado pela comissão: no Artigo 230, a atribuição exclusiva do Estado nas ações de assistência à saúde foi substituída pela possibilidade de ação da iniciativa privada, via contratos e convênios; e no Artigo 231, foram incluídos no SUS apenas os serviços públicos (Cohn apud PEREIRA, 1996, p. 451).

III. 3 As dificuldades de implementação do SUS: a falência da saúde pública no período 1990-94

Os setores conservadores haviam diagnosticado a "falência programada" da saúde pública como conseqüência direta do texto final da Constituição de 1988, que estabelecia a universalização da cobertura da assistência médica, sem a necessária definição de fontes de financiamento (PEREIRA, 1996, p. 450-451). Um bom exemplo dessa visão é o discurso do Deputado Federal Roberto Jeferson (PTB-RJ), um dos líderes do "Centrão" durante a Constituinte: "[...] saúde, direito de todos, dever do Estado; previdência, direito de todos, dever do Estado. Isto é bonito! Porém, isto é fazer reverência com o chapéu dos outros. Nós temos no Brasil 40 milhões de pessoas economicamente ativas; destes 40 milhões, 27 milhões são trabalhadores pagando, e 13 milhões de aposentados usufruindo. Este é um sistema ainda mutualista. Porém, o que foi que fez a Constituinte? Pegou os recursos de 40 milhões, que na realidade são 27 e estendeu para o usufruto de 160 milhões de pessoas sem acrescentar nem mais um centavo. Os recursos da seguridade ainda são formados por $85 \%$ da folha de pagamento, mais $7,6 \%$ de Finsocial, mais $4 \%$ de contribuição sobre o lucro e o restante de concurso de prognóstico. Então para que se quadruplicasse o atendimento da Seguridade Social, que antes era Previdência Social, se injetou $15 \%$ de recursos. Isto é bonito!" (Jeferson apud PEREIRA, 1996, p. 451).

Em um contexto de crise econômica internacional com a necessidade de políticas de ajuste, a decisão política de universalização teria significado simplesmente a inviabilização da previdência social e da assistência à saúde pelo Estado. Ao contrário do esperado aumento do volume de recursos destinados à saúde pública em decorrência da universalização prevista pelo SUS, o que veio a ocorrer de fato foi uma drástica redução dos gastos federais durante o governo Collor (19901992). Segundo Medici, os recursos para a saúde despencaram nesse período, caindo de cerca de US $\$ 11,3$ bilhões para um total de US $\$ 6,5$ bilhões (MEDICI, 1995, p. 132).

A tabela 1 abaixo apresenta a variação do volume total de recursos gastos pelo governo federal com a saúde no Brasil no período de 1989 a 1993:

TABELA 1 - Evolução do gasto federal com saúde no Brasil, de 1989 a 1993 (base de cálculo: US\$ médio de 1992)

\begin{tabular}{|c|c|c|c|}
\hline Anos & $\begin{array}{c}\text { Gasto federal } \\
\text { (US\$ milhões) }\end{array}$ & $\begin{array}{c}\text { Taxa de variacão percentual } \\
\text { anual }\end{array}$ & $\begin{array}{c}\text { Gasto federal per capita } \\
(\text { US } \$)^{3}\end{array}$ \\
\hline 1989 & 11320,3 & - & 80,37 \\
\hline 1990 & 9451,6 & $-16,5$ & 65,86 \\
\hline 1991 & 7847,0 & $-16,9$ & 53,67 \\
\hline 1992 & 6571,2 & $-16,3$ & 44,11 \\
\hline 1993 & 8307,6 & $+26,4$ & 54,73 \\
\hline
\end{tabular}

Fonte: Balanços gerais da União e conta consolidada do gasto social (IPEA-IPLAN apud SOARES, 1999, p. 253).

\footnotetext{
3 Segundo observa Soares (1999), os valores per capita seriam ainda mais reduzidos se calculados de acordo com a cotação
}

média do dólar a valores de 1990, como foi apresentado pelo IPEA em Medici e Oliveira (1992). Exemplos: $1989=$ 55,92; $1990=45,65$. 
Em 1993 e 1994, já durante o mandato de Itamar Franco, o quadro praticamente não se alterou, com gastos médios da ordem de US $\$ 7,5$ bilhões. Mas Medici ressalva que o patamar dos recursos em 1993, apesar do relativo aumento, deveu-se à não efetivação de repasses previstos na Lei Orçamentária daquele ano, em função da revisão do sistema de benefícios da Previdência Social, conforme determinava a Constituição (idem, p. 132). Esse fato elevou os gastos federais com saúde, corroborando as idéias defendidas pelos setores conservadores, como destacamos acima.

Os "repasses" para a área da saúde em 1993, citados por Medici, seriam os recursos da ordem de $15,5 \%$ do total arrecadado da contribuição de empregados e empregadores (SOARES, 1999, $\mathrm{p}$. 253). O redirecionamento desses recursos para a Previdência, segundo Laura Soares, foi o resultado de uma escolha política do Executivo, através do Ministro Antônio Britto: optou-se pela apresentação de uma situação de aparente estabilidade financeira na Previdência, "deixando que a opinião pública considerasse que a crise estava centrada na área da saúde" (1999, p. 254).

Apesar do quadro descrito acima, Medici considera que houve uma compensação com relação ao enxugamento dos recursos federais, pois ocorreu um forte aumento dos gastos com saúde por parte dos municípios, ao lado de um incremento dos gastos estaduais (MEDICI, 1995, p. 132). Essa análise choca-se com denúncias publicadas na imprensa de que, ao contrário dos princípios de descentralização e de municipalização previstos para o SUS, os gastos da União com a saúde pública em 1993 teriam sido da ordem de $72 \%$ do total de gastos públicos no setor (SILVA, 1997, p. 156). Essa informação é confirmada por dados do IPEA, que demonstram que o gasto federal nesse ano foi de cerca de $74 \%$ do total do gasto público com saúde (SOARES, 1999, p. 257).

Os números registrados no início dos anos 90 seriam suficientes para a conformação de um quadro conjuntural para a área da saúde, durante os anos seguintes, que apresentaria como principais características, segundo Medici (1995, p. 132-133):

1. a aceleração da desorganização e do sucateamento do sistema público;

2. a queda dos gastos com programas de alimentação e nutrição, vigilância sanitária e epidemiológica e da Fundação Nacional de Saúde, e

3. o forte crescimento do setor privado complementar.

Em função desse quadro houve uma deterioração das condições de saúde, com o ressurgimento de endemias e o aumento da mortalidade infantil no Nordeste, região sem condições de utilizar recursos próprios para a área da saúde pública (idem, p. 133).

Um outro lado do sucateamento da saúde pública no Brasil no período 1990-1994 diz respeito ao envolvimento da rede operacional do SUS nos grandes esquemas de corrupção engendrados a partir da posse de Fernando Collor, quando se instalou nos principais centros decisórios do Poder Executivo a chamada "República das Alagoas". Um exemplo levantado pela imprensa em relação à área da saúde foi a denúncia de que, no período de janeiro a agosto de 1991, a alocação de verbas do Ministério da Saúde para os estados acusava um repasse per capita de US $\$ 39,33$ para o estado de Alagoas, enquanto São Paulo recebia US\$29,50. Outro fato demonstrativo da ação predatória na gestão do Ministro da Saúde Alceni Guerra diz respeito à Fundação Nacional de Saúde, que assinara contrato para compra de 23500 bicicletas de uma pequena loja a US\$163 a unidade e adquirira 22500 guarda-chuvas de uma empresa de materiais e equipamentos cirúrgicos (!) com um superfaturamento em torno de $50 \%$ (cf. SILVA, 1997, p. 174, 182, 237-296).

A magnitude dessas fraudes - que não afetaram somente os recursos destinados à saúde pública e as denúncias publicadas pela imprensa levaram ao processo de impeachment do Presidente Collor pelo Congresso, em setembro de 1992, e à sua renúncia. É importante deixar claro que diversos tipos de fraudes sempre ocorreram e vêm ocorrendo regularmente no setor público, sendo eventualmente trazidas ao conhecimento da população pela imprensa. O que se registra aqui é a dimensão assumida por essas irregularidades diante de uma situação que se configurava cada dia mais caótica na saúde pública nesse período ${ }^{4}$.

\footnotetext{
4 Uma extensa lista cronológica da ação predatória (rentseeking) na política brasileira de saúde a partir das denúncias veiculadas na imprensa, com destaque para o período do governo Collor, pode ser encon-trada em Silva (1997, p. 237-296).
} 
IV. A SAÚDE PÚBLICA DURANTE O GOVERNO FERNANDO HENRIQUE CARDOSO (1995-2000)

A situação dramática vivida pela saúde pública ocupou lugar de destaque nas eleições presidenciais de 1994, vencidas por Fernando Henrique Cardoso. Apesar das promessas de campanha, porém, o novo governo efetuou nos anos subse-

TABELA 2 - Despesas orçamentárias em programas de saúde, durante o governo Fernando Henrique Cardoso (1995-1998) - em R\$ milhões (de dezembro de 1998) 5

\begin{tabular}{|c|c|}
\hline Ano & Valor \\
\hline 1995 & 17744 \\
\hline 1996 & 15859 \\
\hline 1997 & 14599 \\
\hline 1998 & 14038 \\
\hline Variação 1995-1998 & $-21 \%$ \\
\hline
\end{tabular}

Fonte: Calmon (1999, p. 26).

qüentes à sua posse gastos decrescentes em programas voltados para essa área, como deixa claro o quadro abaixo, baseado em dados apurados pelo Instituto de Pesquisa Econômica Aplicada (IPEA), uma fundação pública vinculada ao Ministério do Planejamento e Orçamento:
Os números apresentados acima fazem parte da evolução de despesas da União em programas de saúde, lançadas contabilmente no Orçamento Fiscal e de Seguridade Social. Apesar dos gastos decrescentes com saúde serem da ordem de $21 \%$,

TABELA 3 - Despesas em saúde e saneamento, durante o governo Fernando Henrique Cardoso (19951998), em $R \$$ milhões

\begin{tabular}{|c|c|c|}
\hline Ano & Orçamento & Gasto total \\
\hline 1995 & 18505 & 19489 \\
\hline 1996 & 16552 & 17148 \\
\hline 1997 & 20677 & 19616 \\
\hline 1998 & 19056 & 16761 \\
\hline
\end{tabular}

Fontes: Rocha (1999, p. 155).

no mesmo período o volume total de despesas em programas sociais da União tiveram um acréscimo de $16 \%$ (CALMON, 1999, p. 26). Se, no mesmo período, agregarmos à rubrica "saúde" os valores relativos ao orçamento e ao gasto total da rubrica "saneamento", teremos a seguinte Tabela:

Portanto, se ignorarmos as variações, ocorridas a cada ano, entre o orçamento e a despesa, o primeiro governo Fernando Henrique Cardoso, apesar do acréscimo de 2,7\% do orçamento para saúde e assistência entre 1995 e 1998, apresenta um déficit de 13,8\% no valor bruto dos gastos totais dessa rubrica no mesmo período.

Entendo que os gastos públicos com saúde devem ser avaliados levando-se em conta uma série de outras variáveis que não cabe aqui destacar, pois fugiria ao escopo deste trabalho. Porém, apesar dos riscos inerentes a uma abordagem superficial, o que importa é a identificação da redução das despesas nessa rubrica por parte da União, no período assinalado. Essa constatação é reforçada por um relatório divulgado pela OPASOMS, que aponta que o gasto federal do Ministério da Saúde representou, em 1996, 10,4\% da arrecadação da União. Este percentual significa um valor muito inferior ao de 1989, da ordem de 19\% (Dain apud OPAS-OMS, 1998, p. 29).

Essa era certamente a constatação do médico Adib Jatene, que, no seu retorno ao Ministério da Saúde logo no início do governo Cardoso, em 1995 (havia sido Ministro também durante o governo Collor, entre fevereiro e setembro de 1992), promoveu uma cruzada em favor de se constituir uma

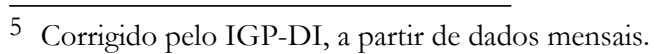


outra fonte de recursos para o financiamento da saúde pública. Para esse fim, Jatene entrou em confronto direto com a área econômica do governo, principalmente com os Ministros da Fazenda, Pedro Malan, e do Planejamento, José Serra e depois Antônio Kandir.

\section{1 O Ministro Adib Jatene e a "cruzada" pelo "imposto da saúde"}

A proposta do Ministro Jatene era a da criação de um imposto intitulado Contribuição Provisória sobre Movimentações Financeiras (CPMF). Ela significaria o retorno do IPMF (Imposto Provisório sobre Movimentações Financeiras), o "imposto do cheque", que vigorara somente em 1994, o último ano do governo Itamar, arrecadando $\mathrm{R} \$ 5$ bilhões para o pagamento de contas da área social. Segundo matéria divulgada pelo imprensa, os ministros Malan e Serra defendiam que, se a CPMF fosse criada, sua arrecadação deveria ser destinada ao pagamento da dívida interna. Já o Presidente da República afirmara, em entrevista, que os gastos do governo na área da saúde haviam duplicado em dois anos, desde quando ele próprio ocupara o posto de Ministro da Fazenda - informação negada pelo Ministro Jatene e pelos dados apurados pelo próprio governo por meio do IPEA. De qualquer forma, Fernando Henrique resolveu transferir para o Congresso o ônus da instituição ou não do novo tributo (Folha de São Paulo, 23.maio.1995).

Jatene tinha também contra si grande parte das bancadas do PSDB, PMDB e PPB e alguns poderosos lobbies: a Federação Brasileira dos Bancos (FEBRABAN), a Confederação Nacional da Indústria (CNI) e um recente Movimento Nacional de Defesa do Contribuinte (MNDC), criado exatamente por setores do empresariado com o objetivo de impedir a criação do novo "imposto do cheque". Essas pressões foram alimentadas pelo entendimento, manifestado publicamente pela área econômica do governo, de que o novo imposto aumentaria a taxa de juros e pressionaria os custos das empresas, "pondo em risco o Plano Real" (Folha de São Paulo, 14.jun.1996; 11.jul.1996). O Ministro da Saúde também foi acusado, inclusive pelo Presidente da República, de ser porta-voz dos interesses dos donos de hospitais privados e representantes das Santas Casas de Misericórdia, que viam no imposto a possibilidade de reajuste dos preços dos serviços prestados ao SUS. Inclusive, como forma de pressão, foi divulgada a informação de que a
Federação Brasileira de Hospitais (FBH) estaria recomendando aos estabelecimentos filiados que simplesmente abandonassem o SUS em razão dos constantes atrasos no repasse das verbas (Folha de São Paulo, 17.out.1995; 11.jan.1996; 29.mar.1996; 14.jun.1996).

Apesar dos conflitos relatados acima, a pressão de Jatene surtiu efeito junto à opinião pública e acabou recebendo o apoio declarado do Presidente Fernando Henrique Cardoso, que passou a ver num imposto totalmente vinculado às despesas com um setor das políticas sociais o impulso necessário para impulsionar positivamente a imagem do governo,

Um outro dado contabilizado na ocasião pelo governo foi o posicionamento da direção do Partido dos Trabalhadores (PT) em votar contra a CPMF, obrigando 22 deputados da bancada do partido, publicamente favoráveis ao imposto, a seguir a deliberação da direção partidária. Esse fato foi visto como elemento importante a ser lançado na disputa em torno da importante Prefeitura de São Paulo nas eleições de 1996, na qual o PSDB apresentava um candidato de peso: o até então Ministro do Planejamento José Serra. Assim, os líderes governistas, após reunião no Palácio do Planalto, decidiram "virar a votação, dada como perdida", obtendo "mais de 30 votos nos últimos 15 minutos de votação" (Folha de São Paulo, 11.jul.1996; 12.jul.1996).

Depois desses contratempos, a empreitada de Jatene finalmente acabou vitoriosa em 22 de outubro de 1996, com a aprovação pelo Congresso da Lei n. 9 311, que regulamentou a CPMF, com recolhimento da alíquota de $0,20 \%$ pelo período previsto de 13 meses. Mas a entrada em vigor do imposto, a partir de janeiro de 1997, não encontraria mais Adib Jatene à frente do Ministério da Saúde.

O relato dos embates envolvendo o Ministro Jatene com os integrantes da área econômica do governo e com o empresariado são importantes porque ilustrativos do tratamento dispensado pelo governo Fernando Henrique Cardoso à saúde pública. A discussão, através da mídia, do Ministro da Saúde com o Presidente da República em relação às contas do Ministério, por exemplo, além da polêmica citada anteriormente, apresentava números que apontavam para um déficit de $\mathrm{R} \$ 2,2$ bilhões no orçamento de 1996 em relação ao ano 
anterior (Folha de São Paulo, 20.jul.1996).

Outra informação importante foi veiculada por ocasião do pedido de demissão do Ministro Jatene, efetuado ao Presidente na última semana de outubro daquele ano - imediatamente após a aprovação da CPMF. Em matéria assinada pelos jornalistas Fernando Rodrigues e Sônia Mossri, a Folha de São Paulo divulgou que um dos motivos da saída de Jatene teria sido a falta de apoio do Presidente Cardoso à sua proposta - possível do ponto de vista legal - de que se utilizasse $\mathrm{R} \$ 1,6$ bilhão da verba do Fundo de Estabilização Fiscal (FEF) para o pagamento das contas do SUS no último trimestre do ano. O Presidente Cardoso teria apoiado a exigência do Ministro do Planejamento Antônio Kandir, de "condicionar a liberação de mais recursos para o SUS ao corte de verbas para áreas como vacinas, controle de endemias e programas de saneamento básico" (Folha de São Paulo, 05.nov.1996). Alguns meses depois, o mesmo jornal revelou que até 20 de julho de 1997 apenas $3 \%$ do total de dinheiro arrecadado pela CPMF (um montante de cerca de $\mathrm{R} \$ 3$ bilhões nesse período) fôra utilizado pelo Ministério da Saúde em ações de saúde preventivas (combate de endemias, saneamento básico e compra de medicamentos). Quase a totalidade dos recursos destinou-se ao pagamento de hospitais conveniados ao SUS e ainda uma pequena parte ao abatimento da dívida contraída pelo ministério da Saúde junto ao Fundo de Amparo ao Trabalhador (FAT) (Folha de São Paulo, 03.ago.1997).

Adib Jatene, em outubro de 1997, denunciava a "total esterilização" da CPMF, pelo governo, como fonte complementar de recursos para a saúde pública. Em artigo para a revista Veja, o exMinistro relatou a sua "cruzada", seus embates com a área econômica, a insuficiência dos gastos do governo brasileiro com a saúde (da ordem de 200 dólares por habitante/ano) e a constatação de que a CPMF foi desviada de sua função original, passando a servir ao objetivo do equilíbrio das contas governamentais (JATENE, 1997).

A denúncia de Jatene é referendada pela mudança de atitude da equipe econômica chefiada por Pedro Malan em relação à CPMF, no último semestre do primeiro governo de Fernando Henrique Cardoso, em 1998. De "imposto para a saúde", a contribuição cada vez menos "provisória" passou a ser entendida como um dos alicerces de sustentação do "ajuste fiscal", inclusive incluído na previsão orçamentária (com o valor estimado de $\mathrm{R} \$ 15,398$ bilhões de arrecadação para 1999) da Carta de Intenções assinada com o FMI e aprovada por essa instituição no dia 2 de dezembro de 1998. Assim, a prorrogação do imposto passou a ser vista como vital para a economia do país, sem a qual não haveria como "garantir o resultado fiscal estimado" e tampouco "dar continuidade ao processo de redução das taxas de juros" (Folha de São Paulo, 28.ago.1997; 24.dez.1998; 31.dez.1998).

Para finalizar o debate sobre o financiamento da saúde pública durante o primeiro governo de Fernando Henrique Cardoso, reproduzo abaixo as tabelas elaboradas por técnicos pertencentes à Diretoria de Estudos Sociais (DISOC) do IPEA, nas quais são discriminadas as fontes de receitas para os programas do Ministério da Saúde. Na tabela referente à distribuição percentual das fontes de financiamento, fica bastante claro o peso acentuado da CPMF no total dos recursos destinados ao Ministério a partir de 1997, em detrimento da perda relativa de recursos através da COFINS (Contribuição Social para o Financiamento da Seguridade Social).

TABELA 4 - Ministério da Saúde: distribuição do gasto, segundo a fonte dos recursos, de 1993 a 1999 (em $\mathrm{R} \$$ milhões de dez.1999)

\begin{tabular}{|c|c|c|c|c|c|c|c|}
\hline Fontes de financiamento & 1993 & 1994 & 1995 & 1996 & 1997 & 1998 & 1999 \\
\hline Recursos ordinários & 1376 & 156 & 703 & 38 & 237 & 2285 & 3201 \\
\hline Títulos resp. Tesouro Nac. & 2320 & 252 & 587 & 648 & 648 & 98 & 166 \\
\hline Operações crédito internas & 402 & - & 1704 & 1598 & - & - & - \\
\hline Operações crédito externas & 71 & 187 & 238 & 165 & 116 & 224 & 316 \\
\hline Recursos diretam. arrecad. & 155 & 333 & 543 & 484 & 561 & 548 & 753 \\
\hline Contribuições sociais & 10377 & 8511 & 15466 & 12268 & 16985 & 15043 & 13621 \\
\hline Contrib. Social Lucro PJ & 1644 & 2014 & 4503 & 4022 & 4492 & 1690 & 2903 \\
\hline Contrib. Soc. Fin. Seg. Soc. & 3869 & 5317 & 10962 & 8246 & 6026 & 5501 & 5798 \\
\hline
\end{tabular}




\begin{tabular}{|c|c|c|c|c|c|c|c|} 
Contrib. Empr.e Trab. Seg.Soc. & 4865 & - & - & - & - & - & - \\
\hline CPMF & - & - & - & - & 6467 & 7852 & 4920 \\
\hline FINSOCIAL - Recup. dep. jud. & - & 1181 & - & - & - & - & - \\
\hline Fundo Estabiliz. Fiscal & - & 5746 & 2665 & 3423 & 4531 & 2814 & 3085 \\
\hline Demais fontes & 684 & 413 & 393 & 725 & 155 & 157 & 648 \\
\hline Total & 15385 & 15599 & 22299 & 19351 & 23233 & 21170 & 21791 \\
\hline
\end{tabular}

Fonte: Reis, Ribeiro e Piola (2001, p. 13)

TABELA 5 - Ministério da Saúde: distribuição percentual das fontes de financiamento, de 1993 a 1999

\begin{tabular}{|c|c|c|c|c|c|c|c|}
\hline Fontes de financiamento & 1993 & 1994 & 1995 & 1996 & 1997 & 1998 & 1999 \\
\hline Recursos ordinários & 8,9 & 1,0 & 3,2 & 0,2 & 1,0 & 10,8 & 14,7 \\
\hline Títulos resp. Tesouro Nac. & 15,1 & 1,6 & 2,6 & 3,3 & 2,8 & 0,5 & 0,8 \\
\hline Operações crédito internas & 2,6 & - & 7,6 & 8,3 & - & - & - \\
\hline Operações crédito externas & 0,5 & 1,2 & 1,1 & 0,9 & 0,5 & 1,1 & 1,4 \\
\hline Recursos diretam. arrecad. & 1,0 & 2,1 & 2,4 & 2,5 & 2,4 & 2,6 & 3,5 \\
\hline Contribuições sociais & 67,4 & 54,6 & 69,4 & 63,4 & 73,1 & 71,1 & 62,5 \\
\hline Contrib. Social Lucro PJ & 10,7 & 12,9 & 20,2 & 20,8 & 19,3 & 8,0 & 13,3 \\
\hline Contrib. Soc. Fin. Seg. Soc. & 25,1 & 34,1 & 49,2 & 42,6 & 25,9 & 26,0 & 26,6 \\
\hline Contrib. Epmr.e Trab. Seg. Soc. & 31,6 & - & - & - & - & - & - \\
\hline CPMF & - & - & - & - & 27,8 & 37,1 & 22,6 \\
\hline FINSOCIAL- Recup. dep. jud. & - & 7,6 & - & - & - & - & - \\
\hline Fundo Estabiliz. Fiscal & - & 36,8 & 12,0 & 17,7 & 19,5 & 13,3 & 14,2 \\
\hline Demais fontes & 4,4 & 2,6 & 1,8 & 3,7 & 0,7 & 0,7 & 3,0 \\
\hline Total & 100,0 & 100,0 & 100,0 & 100,0 & 100,0 & 100,0 & 100,0 \\
\hline
\end{tabular}

Fonte: Reis, Ribeiro e Piola (2001, p. 14).

\section{2 O SUS e a descentralização da gestão de saúde}

Apesar dos números que atestavam a precariedade de condições vivida pela saúde pública, sempre arrolados por Jatene para justificar a defesa da CPMF, o novo Ministro da Saúde, Carlos César Albuquerque, empossado em 13.dez.1996 (ficaria na função até 31.mar.1998), afirmara à imprensa que o problema do setor não seria exatamente "o da falta de recursos mas sim o modo de administrálos" (ELIAS, 1997, p. 205). Em função disso, duas questões poderiam ser arroladas como parte integrante e prioritária da agenda do novo Ministro da Saúde: a municipalização e o debate sobre as formas de ressarcimento ao SUS do atendimento proporcionado à clientela dos planos e seguros de saúde privados.

A organização e o funcionamento do SUS foi regulamentada pela Lei n. 8 080, de 19.set.1990 a Lei Orgânica da Saúde - e pela Lei Complementar n. 8 142, de 28.dez.1990, que dispõe, entre outras

\footnotetext{
6 Efetuou-se arredondamento da tabela original, elaborada com a utilização de uma casa decimal.
}

questões, sobre as transferências intergovernamentais de recursos financeiros na área da saúde (CORDEIRO, 1991; OLIVA-AUGUSTO \& COSTA, 2000, p. 201-202).

A destinação de recursos federais ao SUS toma como base a receita estimada para o orçamento da seguridade social, conforme as metas estabelecidas anualmente na Lei de Diretrizes Orçamentárias da União. Os recursos são administrados pelo Fundo Nacional de Saúde (FNS) e fiscalizados por um órgão colegiado, o Conselho Nacional de Saúde, do qual participam representantes do governo, usuários, profissionais de saúde e prestadores de serviços.

O Ministério da Saúde é a instância que, na administração do FNS, acompanha a aplicação dos recursos que são repassados a estados e municípios. Estes, por sua vez, são obrigados a constituir os seus respectivos fundos de saúde e conselhos estaduais e municipais, elaborar planos de ação e apresentar relatórios de gestão, garantindo também a existência de contrapartida de recursos para a saúde nos seus orçamentos (OLIVA-AUGUSTO \& COSTA, 2000, p. 202-203). 
Somente três anos após a Lei Orgânica da Saúde é que os critérios para o repasse de recursos do governo federal para estados e municípios foram sistematizados (Norma Operacional Básica do SUS - NOB-93 -, anexa à Portaria do Ministério da Saúde n. 545, de 20.maio.1993). A NOB-93 entrou em vigor em 1994, estabelecendo responsabilidades, requisitos e prerrogativas para a gestão local (estados e municípios) do SUS, sob três modalidades: gestão incipiente, gestão parcial e gestão semiplena.

Apenas na modalidade de gestão semiplena é que se pode falar em efetiva municipalização dos recursos e da administração da saúde pública. Nesse tipo de gestão, o município assume a responsabilidade total sobre a gestão da prestação de serviços; o gerenciamento da rede pública (exceto da rede estadual), e o recebimento mensal dos recursos financeiros para custeio dos tetos ambulatoriais e hospitalares (idem, p. 203).

Em dezembro de 1996, quando se empossou o Ministro Albuquerque, eram poucos os municípios brasileiros que se encontravam integrados de maneira plena ao Sistema Único de Saúde. Até janeiro de 1997, 3127 municípios brasileiros (58\% do total de 5407 municípios existentes naquela data) foram cadastrados pelo Ministério da Saúde como habilitados a uma das modalidades de gestão local do SUS. Desses, somente 144 (5\%) foram contabilizados como atendendo à condição de gestão semiplena (Arretche apud OLIVA-AUGUSTO \& COSTA, 2000, p. 204). O quadro abaixo mostra a evolução das modalidades de gestão local no período 1994-1996:

TABELA 6 - Descentralização do SUS (1994-1996): número de municípios habilitados à gestão local (NOB93)

\begin{tabular}{|c|c|c|c|}
\hline Condição de gestão local & 1994 & 1995 & 1996 \\
\hline Incipiente & 1836 & 2131 & 2369 \\
\hline Parcial & 537 & 612 & 619 \\
\hline Semiplena & 24 & 56 & 137 \\
\hline Totais & 2397 & 2799 & 3125 \\
\hline
\end{tabular}

Fonte: Oliva-Augusto e Costa (2000, p. 204).

O Relatório sobre o desenvolvimento humano no Brasil, referente a 1996, publicado pelo IPEA para o Programa das Nações Unidas para o Desenvolvimento (PNUD), analisa a experiência do governo brasileiro na descentralização das políticas sociais voltadas para a saúde. Na avaliação apresentada pelo PNUD, a "resistência" à gestão semiplena pelos municípios deve ser creditada a duas causas: (1) "uma atitude de prudência" dos municípios, diante das incertezas quanto ao repasse dos recursos pelo governo federal; (2) a resistência refletiria "uma posição confortável de acomodação" dos governantes locais, não se envolvendo com problemas de desgaste político que poderiam advir da administração do sistema de saúde no âmbito do município (PNUD, 1996, p. 60).

Segundo extensa matéria publicada pelo jornal Gazeta Mercantil, em fevereiro de 1997, sob o título "Crise dramática do SUS", essa sistemática de descentralização adotada na organização do SUS era vista como uma das principais responsáveis pelo sucateamento do sistema público de saúde. A questão que se colocava naquele momento, mais uma vez, dizia respeito aos recursos que seriam repassados pelo governo federal aos estados e municípios. Apesar do volume de despesas da ordem de $\mathrm{R} \$ 191,7$ milhões para pagamento aos hospitais e do montante de R $\$ 230,7$ milhões para os ambulatórios, o grande problema alegado por hospitais e clínicas era a defasagem existente entre os valores da tabela utilizada pelo governo para ressarcimento dos procedimentos efetuados nas redes de assistência médica e hospitalar e os custos dos mesmos. Como exemplo, os profissionais de medicina recebiam, em 1996, o valor de cerca de dois dólares apenas por cada consulta e os hospitais recebiam cerca de três dólares por diária de um paciente. Mesmo com um aumento de $25 \%$, a partir de março de 1997 , esses valores estimulavam fortemente as fraudes e a deterioração dos serviços, "prejudicando as camadas mais pobres, que não podem pagar um plano de saúde", como atesta o pesquisador do IPEA Francisco de Oliveira. Segundo ele, o SUS é "uma ótima idéia", mas o funcionamento precário do sistema é "produto da hipocrisia governamental", que não o implanta de maneira efetiva em razão da necessidade de não perder o controle político sobre a gestão dos recursos financeiros. 
Já o Ministério da Saúde, através do Secretário de Assistência à Saúde, Antônio Joaquim Werneck de Castro, negava que houvesse falta de vontade política do governo na implantação do sistema, assim como rejeitava também a idéia de que a nãoefetivação da gestão local estivesse sendo provocada pela insegurança das prefeituras em assumir a responsabilidade do atendimento à saúde, sem garantias efetivas de cobertura por parte do governo federal.

Uma outra informação relevante, apresentada pela matéria citada, diz respeito à rede privada conveniada ao SUS. Segundo a Federação das Misericórdias do Estado de São Paulo, entidade representativa de 423 Santas Casas paulistas, a única saída para a rede, em termos de financiamento alternativo ao SUS, seria a criação de planos de saúde próprios. José Alberto Monteclaro César, Presidente da Federação, informava sobre a existência de 80 planos de Santas Casas, criados desde o início da década de 90 , e a iniciativa de fundação do Instituto Brasileiro de Planos de Saúde das Santas Casas e Hospitais Filantrópicos, com o objetivo de coordenar e integrar os planos existentes e ainda ajudar na criação de novos. Como as Santas Casas, segundo Monteclaro César, eram responsáveis por $68 \%$ dos leitos e $60 \%$ dos atendimentos do SUS no estado, a crise, decorrente da defasagem dos valores e dos ressarcimentos com atraso de até 50 dias, assumiam proporções gigantescas (Gazeta Mercantil, 21.fev.1997; 22.fev.1997; 23.fev.1997).

A situação descrita a respeito da política de descentralização do SUS foi alterada no início de 1998, quando o governo Fernando Henrique Cardoso implementou uma nova Norma Operacional Básica, a NOB-96, anexa à Portaria n. 2 203, de 05.nov.1996, do Ministério da Saúde, revendo o processo de municipalização. A NOB96 promove ofortalecimento do papel dos estados na coordenação dos programas vinculados ao SUS, revertendo o poder de gestão concedido aos municípios pela NOB-93. Também reorganizou o sistema, de modo a priorizar a atenção básica à saúde, fortalecendo a "focalização", conforme foi proposto pelos organismos financeiros internacionais (Almeida apud OLIVA-AUGUSTO \& COSTA, 2000, p. 204). A "focalização" consiste na política de saúde direcionada para os estratos mais pobres da população. Ela volta a reproduzir uma política segmentada, orientada para a renda da população, indo portanto na contramão da universalização proposta em 1988.

Além dessa modificação substantiva, a medida altera as modalidades de gestão local do SUS. Agora elas são duas: a gestão plena da atenção básica e a gestão plena do sistema de saúde. $\mathrm{Na}$ primeira modalidade, os municípios passam a responder totalmente pela assistência ambulatorial, pelas ações básicas de vigilância sanitária e epidemiológica, pela gerência de todas as unidades básicas de saúde pública existentes na região e responsabilizam-se pela oferta de atendimento intermunicipal, abarcando cidades vizinhas. $\mathrm{Na}$ segunda modalidade, os municípios, além das ações da atenção básica, passam também a responder integralmente por todas as ações referentes aos serviços do SUS em sua jurisdição, inclusive a oferta de procedimentos de alta complexidade tecnológica.

Segundo informações do governo Cardoso, dos 5507 municípios existentes em 1998, 4.885 $(89 \%)$ estavam habilitados ao atendimento pela modalidade gestão de atenção básica, enquanto 431 (8\%) apresentavam-se na condição de gestão plena do sistema de saúde (OLIVA-AUGUSTO \& COSTA, 2000, p. 204-205).

IV.3 Em busca de recursos para o SUS: a luta pelo ressarcimento de despesas pela iniciativa privada

Quando o Ministro Carlos Albuquerque referiuse à má utilização dos recursos públicos na área da saúde, falava da questão do ressarcimento ao SUS dos recursos gastos no atendimento da clientela que paga os planos de saúde privados. Nesse sentido, o Ministério da Saúde, sob a sua gestão, enviou projeto à Câmara dos Deputados, em maio de 1997, visando à regulamentação dos planos e seguros privados, criando também um fundo de cerca de $\mathrm{R} \$ 3$ bilhões, formado em parte por dinheiro público e em parte pela taxação sobre o faturamento das empresas privadas de planos e seguros de saúde. Na verdade, tratava-se de uma reedição do projeto de lei encaminhado pelo exMinistro Jatene ao Congresso em março de 1996, tratando da mesma questão (JATENE, 1997). O objetivo do projeto encaminhado por Albuquerque era financiar com esses recursos os tratamentos de alto custo, como transplantes, cirurgias cardíacas e doenças graves como câncer e Aids, os quais não são cobertos pelos contratos dos 
planos de saúde, ficando sob responsabilidade do SUS, que gasta neles metade do que investe cerca de R \$1,3 bilhão ( $O$ Globo, 27.maio.1997).

A proposta do Ministro Albuquerque, segundo o jornalista Elio Gaspari, teria dois problemas complementares: "usa o Estado para socorrer a iniciativa privada (bancando os tratamentos caros) e suga a iniciativa privada para financiar a máquina do Estado (usando o dinheiro do fundo para os doentes do SUS)" (GASPARI, 1997). Ele acusou o projeto de preservar a "distorção" existente nos planos oferecidos pela iniciativa privada, que oferecem cobertura para a saúde de pessoas "jovens e sadias" e repassam para a rede pública os idosos e as doenças mais graves.

A criação de um fundo para o financiamento de tratamentos de alto custo também foi questionada pelo mercado privado de saúde, principalmente pelas companhias de seguros. Horácio Cata Preta, Presidente da Comissão de Seguro-Saúde da Federação Nacional das Empresas de Seguros Privados e Capitalização (FENASEG), afirmou que a iniciativa criaria problemas entre as empresas e os usuários, já que "o governo vai arrecadar, mas não conseguirá prestar o serviço de alto custo, que acabará sendo assumido pelas seguradoras", gerando encargos adicionais para os segurados que, portanto, arcariam com os custos em duplicidade. Outra questão levantada por Cata Preta diz respeito ao formato do projeto de regulamentação: além de ter característica de imposto - e, por isso, teria de obedecer aos respectivos trâmites legislativos legais -, apresentava-se como uma espécie de "bitributação", já que, em um artigo, obrigava as empresas a contribuir para o Fundo; em outro, obrigava as empresas a ressarcir ao SUS pelo atendimento efetuado aos seus clientes ( $O$ Globo, 27.maio.1997; 29.maio.1997). De qualquer forma, tanto pelas suas inconsistências, quanto pela falta de apoio político, o projeto de ressarcimento mais uma vez não se viabilizou naquele momento, voltando à discussão mais adiante, durante a gestão Serra.

\section{4 O Ministério da Saúde como força política? A gestão José Serra (1998-2000)}

O economista e Senador José Serra (PSDBSP) assumiu o Ministério da Saúde, em 31 de março de 1998, na condição de um nome forte do partido governista para a sucessão de Fernando Henrique Cardoso na Presidência da República, em 2002. Serra passaria a ocupar a posição de uma das alternativas possíveis entre os dois nomes de presidenciáveis da área social, juntamente com o Ministro da Educação, Paulo Renato Souza. O outro nome governista, que poderia ser utilizado em função da conjuntura sucessória, seria o do Ministro da Fazenda, Pedro Malan, que apareceria como o grande responsável pela manutenção da estabilidade econômica, condição sine qua non para a retomada de um desenvolvimento econômico sustentado.

Para a concretização dessa estratégia em torno do nome de José Serra, no entanto, seria necessário o estabelecimento de condições políticas que lhe trouxessem visibilidade nos meios de comunicação e força política suficiente para o enfrentamento das questões urgentes em torno da área de saúde no Brasil. Um dos pré-requisitos nesse sentido seria dotar o próprio Ministério da Saúde de força política. Esse Ministério sempre teve um papel menor e desprestigiado no conjunto dos ministérios do governo federal. Além do papel preponderante assumido pela tecnoburocracia em torno do Ministério da Previdência e Assistência Social - objeto, inclusive, dos debates do movimento sanitarista -, o novo Ministro teria de desfazer a imagem de "pedinte com o chapéu estendido", que marcou a presença do Ministro Adib Jatene junto à mídia.

Aceito o desafio, Serra defrontou-se com as metas do ajuste fiscal do governo federal, acertadas nos acordos assinados com o Fundo Monetário Internacional. A questão orçamentária passou a ser, então, um dos alvos prioritários estabelecidos pelo novo Ministro da Saúde, que tratou de encampar o Projeto de Emenda Constitucional (PEC) para o aumento dos recursos para o SUS, apresentado no Congresso pelo Deputado Federal Eduardo Jorge (PT-SP). Esse projeto, segundo Serra, não resultaria em prejuízo da política de estabilidade conduzida pela equipe econômica, já que a verba para a saúde seria proveniente da redistribuição percentual dos recursos já previstos no orçamento pela Constituição de 1988, no Artigo 55 do Ato das Disposições Constitucionais Transitórias7. A novidade do "PEC da saúde" seria a vinculação obrigatória desses recursos aos orça-

\footnotetext{
7 O texto do Artigo 55 do ADCT diz o seguinte: "Até que seja aprovada a lei de diretrizes orçamentárias, trinta por cento, no mínimo, do orçamento da seguridade social, excluído o seguro-desemprego, serão destinados ao setor de saúde”.
} 
mentos federal, dos estados e dos municípios. A idéia da sua vinculação seria uma forma de proteger as verbas destinadas à área da saúde da sua habitual transferência em situações de crise financeira, para cobrir os rombos ou políticas de emergência em outras áreas como, por exemplo, a previdência ou a assistência social, como já ocorrera em 1991 e em 1993 (SERRA, 2000). Essa flexibilidade invariavelmente punia a área da saúde em virtude da sua pouca visibilidade política nos períodos eleitorais, em detrimento, por exemplo, da criação de frentes de trabalho contra a seca no Nordeste, ou a sustentação de um percentual razoável numa política de valorização do salário mínimo.

$\mathrm{Na}$ defesa da proposta, Serra reafirmou sua idéia de "impedir que a saúde seja um colchão amortecedor de crises financeiras como foi no passado". Ao mesmo tempo, ligou o aumento dos recursos destinados à saúde ao crescimento do produto interno bruto, ou seja, à expectativa de retomada do crescimento econômico. Assim, estimava que as despesas com o SUS, em torno de $\mathrm{R} \$ 30$ bilhões, em 1999 - cerca de 2/3 na esfera federal e o restante sob responsabilidade dos estados e municípios -, poderiam, dependendo do aumento do PIB, crescer cerca de $30 \%$ ou $40 \%$ (SERRA, 1999; 2000).

A proposta de vinculação orçamentária encontrou forte oposição interna no governo, sendo criticada pelo Ministro da Fazenda, Pedro Malan, e por lideranças governistas do PSDB, como o governador Tasso Jereissati (CE) e do PFL, como o Presidente do Senado, Antônio Carlos Magalhães (BA).

Em 1999, proposta semelhante de Emenda Constitucional, vinculando os recursos orçamentários ao SUS, apresentada pelo Senador Antônio Carlos Valadares (PSB-SE), fôra derrotada no Senado, em segundo turno, por apenas dois votos. A principal oposição à emenda, naquela ocasião, partiu da bancada do PFL. Segundo um dos seus membros, o Senador Paulo Souto (PFL-BA) pertencente ao grupo político do Senador Antônio Carlos Magalhães -, a oposição do partido ao projeto estava relacionada a uma "posição conceitual" contra a idéia de vinculação, ou seja, a existência de quaisquer vinculações orçamentárias tornaria sem sentido o trabalho dos legislativos estaduais e municipais.

O Projeto de Emenda Constitucional do Deputado Eduardo Jorge, apresentado também em
1999, fôra aprovado pela Câmara dos Deputados. Mas como a outra proposta, do Senador Valadares, foi rejeitada nesse mesmo ano, o Presidente do Senado, Antônio Carlos Magalhães, argumentando a existência de uma questão regimental, retirou o "PEC da saúde" da apreciação pela Comissão de Constituição e Justiça (CCJ). O Senador Magalhães referia-se a uma norma constitucional que impossibilita que duas emendas, tratando do mesmo assunto, sejam apreciadas numa mesma sessão legislativa.

Em abril de 2000, superado o problema regimental, o Ministro Serra procurou mobilizar os membros do Conselho Nacional dos Secretários Estaduais e Municipais de Saúde (CONASEMS) e do Conselho Nacional de Saúde (CNS), do qual era Presidente, para que exercessem pressão sobre o Presidente do Senado, no sentido de agilizar a votação da emenda. Em reunião do CNS, convocado extraordinariamente por Serra, formouse um "núcleo estratégico de mobilização", encarregado de organizar o lobby entre os Senadores. Paralelamente, Serra começou a acenar com a situação "dramática" do SUS, alegando que, com a aprovação da emenda, poderia passar a receber recursos da ordem de $\mathrm{R} \$ 2,2$ bilhões.

Paralelamente a essa mobilização comandada pelo Ministro Serra em relação ao "PEC da saúde", as verbas para o setor poderiam ter vindo também da Lei de Diretrizes Orçamentárias (LDO), aprovada pelo Congresso para o ano 2000. Na LDO, deputados das bancadas do Nordeste conseguiram incluir a vinculação das receitas para o SUS em cerca de $\mathrm{R} \$ 1,5$ bilhão. $\mathrm{O}$ dispositivo apresentado pelos parlamentares obrigava o governo a priorizar o SUS na destinação de todos "os créditos suplementares referentes aos excessos de receita obtidos durante o ano". Mas, da mesma forma que o projeto apresentado no ano anterior pelo Senador Valadares e o PEC em tramitação no Senado, o mecanismo de vinculação das receitas continuava encontrando rejeição por parte do PFL.

A novidade em abril de 2000 foi a entrada em cena do Ministro do Planejamento, Orçamento e Gestão, Martus Tavares, que comunicou à imprensa a sua intercessão junto ao Presidente Fernando Henrique Cardoso no sentido de vetar a emenda à LDO que vinculava os gastos ao SUS. De fato, em 11 de maio de 2000, a lei foi sancionada pelo Presidente da República com dois vetos - um deles exatamente o que garantia os 
recursos para a saúde de modo vinculado. A justificativa da Presidência, apresentada na ocasião pelo Ministro Martus Tavares, era de que "o dispositivo dando prioridade ao SUS engessava a execução do orçamento, até para ações de emergência de combate a epidemias e enchentes" (Jornal do Brasil, 01.abr.2000; 20.abr.2000; 24.abr.2000; 12.maio.2000).

Apesar desse revés, ocorrido em maio, o Ministro José Serra finalmente saiu vitorioso na sua mobilização pela garantia de verbas para o SUS, conseguindo aprovar no Senado, em dois turnos, em 10 de agosto de 2000, a Emenda Constitucional n. 29, que vincula os recursos orçamentários à saúde pública. A proposta, relatada pelo Senador Antônio Carlos Valadares (PSB-SE), obteve o apoio de todos os partidos de oposição, o que resultou em 67 votos favoráveis ( 5 a mais do que no primeiro turno) e 2 votos contrários, dos senadores Paulo Souto (PFL-BA) e Lúcio Alcântara (PSDB-CE).

A Emenda Constitucional n. 29 fixou o montante federal para a saúde de acordo com a variação do produto interno bruto (PIB). Já os estados e os municípios foram obrigados a destinar, cada, $7 \%$ dos recursos para a saúde no primeiro ano. Nos anos seguintes, os estados e municípios deverão aumentar esses recursos para, respectivamente, $12 \%$ e $15 \%$. A expectativa do Ministério da Saúde é de que o setor disponha de mais R $\$ 4$ bilhões até o fim do quinto ano de vigência da nova lei (Valor Econômico, 10.ago.2000; O Estado de São Paulo, 11.ago.2000).

Apesar do silêncio da área econômica do governo em relação à aprovação do "PEC da saúde", o ex-Presidente do Banco Central, o economista Gustavo Franco, assumiu o papel de porta-voz da insatisfação do mercado com a decisão do Senado. Além de assinalar que o ajuste fiscal recebera "um duro golpe", acusou o Ministro Serra de agir contra o erário ao defender a vinculação de recursos orçamentários para a saúde. O problema, segundo Franco, não se prendia exatamente à questão da saúde, mas sim a qualquer tipo de vinculação, que compromete ainda mais a capacidade de gerenciamento do Orçamento Geral da União por parte do governo, já prejudicada pelas diversas vinculações constitucionais efetivadas desde 1988. Ironicamente, Gustavo Franco relembra o artigo sobre o assunto, escrito em 1987 pelo Presidente da Comissão de Tributação, Orçamento e Finanças da Constituinte, o então deputado José Serra. Na ocasião, Serra era um inimigo declarado das vinculações, em razão de que elas "castram o poder que o Legislativo deve exercer num regime democrático em relação à utilização dos recursos públicos; são tecnicamente inadequadas, induzem a distorções e são impróprias a um texto constitucional" (FRANCO, 2000).

Um outro ponto importante na agenda do Ministro José Serra dizia respeito à regulamentação dos planos e seguros de saúde privados. Havia uma ausência completa de regulamentação dos planos de saúde pertencentes às empresas de medicina de grupo e cooperativas médicas, que haviam se tornado "campeãs de queixas" nos órgãos de defesa do consumidor, como os PROCONs (Fundações de Proteção e Defesa do Consumidor). Os planos de saúde surgiram como uma alternativa para a assistência à saúde principalmente da classe média, em razão das péssimas condições de atendimento proporcionadas pelo SUS. Atento a essa questão, que afetava cerca de 40 milhões de pessoas, o Ministro da Saúde entrou na linha de frente da regulamentação, conseguindo aprovar, em 1998, a Lei dos Planos de Saúde (Lei n. 9 656) seguida, no final de 1999, da criação de um órgão regulador para o setor privado, a Agência Nacional de Saúde Suplementar (ANS).

Portanto, assim como na aprovação do "PEC da saúde", o Ministro Serra saiu vitorioso em mais um embate com o Ministério da Fazenda, já que conseguiu definir a área da saúde como o locus regulatório para esse segmento do mercado, em parte regulado até então pela SUSEP (Superintendência Nacional de Seguros Privados), ligada ao Ministério da Fazenda (Folha de São Paulo, 04.nov.1998; SERRA, 1999).

Outra questão de relevância da agenda ministerial de José Serra referia-se aos preços elevados dos medicamentos farmacêuticos. A indústria farmacêutica teve aumentos superiores aos da inflação após o Plano Real. Logo, agir contra esse poderoso lobby seria uma evidente prova de força de um Ministro com pretensões presidenciais. A questão também dava uma grande visibilidade na mídia.

No início de 1999 a opinião pública foi tomada de perplexidade diante das denúncias de produção e distribuição de remédios falsificados, desenca- 
deadas a partir da Comissão Parlamentar de Inquérito dos Medicamentos no Congresso. Nesse contexto, assumiu grande importância na época a criação de um outro órgão de caráter regulatório, a Agência Nacional de Vigilância Sanitária (ANVISA). Essa agência foi implantada pela Lei n. 9782 , de 26 de janeiro de 1999, estando vinculada ao Ministério da Saúde e acompanhada pela sociedade através do Conselho Nacional de Saúde. Apresentou-se com o objetivo de regular a produção, a comercialização e a distribuição de produtos e serviços sujeitos à vigilância sanitária, ou seja, medicamentos, cosméticos e alimentos (COSTA et alii, 2000, p. 70-72).

No início de 2000, o Ministro Serra tornou pública a proposta de procurar baixar os preços dos medicamentos através da produção e da oferta, no mercado, de remédios genéricos medicamentos de uso popular que apresentariam o mesmo princípio ativo que os de referência, produzidos pelos laboratórios multinacionais. $\mathrm{O}$ medicamento genérico seria vendido a preços muito inferiores aos dos laboratórios farmacêuticos. A medida, como não podia deixar de ocorrer, significou um conflito aberto com a poderosa indústria farmacêutica, que passou a questionar a eficácia no uso desses medicamentos e tem comandado, nos bastidores, uma ação de rejeição à produção e à distribuição dos genéricos no mercado. A tática do Ministro da Saúde nessa questão continuou sendo a da ampliação da oferta no mercado. Nesse sentido, chegou ao ponto de efetuar visita à Índia, com o objetivo de atrair um dos seus maiores laboratórios para produzir medicamentos genéricos no Brasil (Jornal do Brasil, 25.jul.2000).

$\mathrm{O}$ último round dos conflitos entre o governo, via Ministério da Saúde, e a indústria farmacêutica, em julho de 2000, continuou tendo como motivo os preços dos medicamentos. Como a política de estabilização do Plano Real não recorreu ao controle dos preços, deixou de haver poder para controlar e fiscalizar os preços oferecidos ao consu-midor. Em julho, após os aumentos promovidos pelos laboratórios, o governo ameaçouos com uma proposta de congelamento dos preços. A ameaça foi travestida em acordo, através da assinatura de um protocolo, entre três ministérios (Saúde, Fazenda e Justiça) e representantes de alguns laboratórios, no qual estes se comprometeram a não aumentar os preços dos remédios até o final de $2000^{8}$.

Como se percebe pelos embates travados, a atuação do Ministro José Serra em busca do fortalecimento do Ministério da Saúde e de seu próprio fortalecimento político foi bastante difícil. Saudado como um Ministro pioneiro, que "parece dar o primeiro passo para acabar com o 'ralo' da ineficiência e da corrupção" no setor de saúde (DUPAS, 1998), Serra enfrentou, como ele próprio admitiu, questões que se encontravam fora de sua alçada, como a grande desigualdade e concentração de renda, os cortes que vêm sendo efetuados nos investimentos em saneamento básico e a insuficiência do orçamento para a área de saúde.

Assim, não foi com total surpresa que ele recebeu o relatório da OMS de 2000, que apontava o sistema de saúde do Brasil como "um dos piores do mundo". O Ministro teve uma reação indignada e acusou de "má-fé" a avaliação da OMS, que "prejudica a imagem do país no exterior" (Jornal do Brasil, 21.jun.2000; 22.jun.2000).

Pela análise efetuada acima, fica claro que o Ministro José Serra é uma opção de peso do PSDB para a sucessão do governo Fernando Henrique Cardoso nas eleições de 2002. A construção de uma imagem pública vitoriosa nos embates contra interesses poderosos reforça a idéia de que o Ministério da Saúde é uma excelente plataforma para o lançamento de Serra como candidato de apelo popular (Valor Econômico, 10.ago.2000; O Estado de São Paulo, 20.ago.2000). Serra foi o primeiro Ministro a sair vitorioso na garantia de maiores recursos para a saúde pública, enfrentando o ajuste fiscal e o seu guardião - o Ministro da Fazenda Pedro Malan - alguns governadores dos estados, com destaque para Tasso Jereissati (PSDB-CE) e a bancada do PFL no Senado, liderada pelo Presidente da Casa, Antônio Carlos Magalhães, todos contrários à vinculação orçamentária dos recursos.

Nesse período de dois anos (1998-2000), no qual lutava contra a escassez de verbas, Serra

\footnotetext{
8 Sobre isso, dois pontos merecem destaque: em primeiro lugar, o fato de que a adesão das empresas ao protocolo "não é obrigatória"; em segundo lugar, o aviso feito pelo Presidente da Associação Brasileira da Indústria Farmacêutica (ABIFARMA), José Eduardo Bandeira de Mello, de que os preços dos remédios deveriam ficar "muito caros" com o fim da "trégua", em janeiro de 2001 (Jornal do Brasil, 25.jul.2000; 26.jul.2000; 27.jul.2000; 30.jul.2000).
} 
estabeleceu uma pauta política que, além de ter sido também vitoriosa, teve o efeito adicional de garantir a presença constante do seu nome junto à mídia, funcionando como uma perfeita estratégia de marketing. Foi o caso da regulamentação dos planos e seguros privados de saúde, que culminou com a criação da ANS. Além do enfrentamento do lobby das empresas privadas de saúde, até então sem qualquer tipo de regulação pelo Estado, a criação da ANS representou outra vitória contra Malan e a equipe econômica, em especial a SUSEP que, além de pretender continuar como responsável pela fiscalização do seguro-saúde, pretendia abarcar os outros segmentos privados.

Outro ponto destacado foi o conflito aberto pelo Ministro contra os preços praticados pela indústria farmacêutica, tanto no que concerne à lei que introduziu os medicamentos genéricos, quanto na concretização do acordo que teria garantido o congelamento de preços dos remédios durante o segundo semestre de 2000. Apesar do acordo visando ao congelamento ter sido conduzido pelas autoridades da área econômica, o resultado acabou sendo capitalizado por Serra, que vinha denunciando como abusivos os preços praticados pela indústria farmacêutica. A luta principal, nesse caso, foi contra os poderosos interesses que administram esse setor, majoritariamente composto por multinacionais de grande porte, que passaram a deter a total hegemonia desse mercado a partir de uma estratégia montada nos bastidores do regime militar (cf. EVANS, 1982). Também em relação a esse ponto, merece destaque, durante a gestão Serra, a criação de outra agência regulatória para o mercado, a ANVS. Esta surgiu num contexto de inúmeras denúncias contra a fabricação e a venda de remédios falsificados, que havia resultado na CPI dos Medicamentos, instalada no Congresso em 1998. As ações de Serra que se destacaram nesse processo foram o maior controle e a fiscalização sobre farmácias e drogarias, exigindo a presença de profissionais qualificados com curso superior (uma exigência legal), e a tentativa de inibir a chamada "empurroterapia" - a prática costumeira dos balconistas em receitar remédios para a população, sobre os quais geralmente recebiam uma comissão paga pelo fabricante e/ou distribuidora. Essa prática tinha ainda o agravante de esses remédios, às vezes, não produzirem qualquer efeito sobre a doença (durante a CPI dos Medicamentos esses remédios ficaram conhecidos como B.O. - "bons para otário", termo comumente utilizado pelos balconistas em relação à população, segundo depoimento efetuado pelo representante do comércio varejista das farmácias e drogarias).

Além dos pontos destacados acima, contabilizou-se como vitória pessoal do Ministro José Serra a proposta, aprovada no Congresso no primeiro semestre de 2000, de restrição à propaganda de cigarros nos meios de comunicação. Essa proposta acompanha as diretrizes da Organização Mundial de Saúde (OMS) no combate ao câncer, visando a estabelecer um tratado mundial contra o fumo. Além da resistência de outro poderoso lobby - o da indústria do tabaco -, Serra contornou também a pressão política da maior parte da bancada de parlamentares do Rio Grande do Sul, onde 150 mil famílias trabalham na lavoura do fumo (Jornal do Brasil, 23.maio.2000; 08.jun.2000; 15.jun.2000; Valor Econômico, 10.ago.2000).

Outro ponto importante das políticas envolvendo a saúde pública foi a implementação, pelo Ministério da Saúde, do Programa de Atenção Básica (PAB), em janeiro de 2000, envolvendo União, estados e municípios em ações de prevenção baseadas na instituição do médico de família para comunidades carentes. O programa foi inspirado na experiência cubana e tem funcionado principalmente nas pequenas localidades do interior do país. Segundo dados do Ministério, em agosto de 2000 as Equipes de Saúde da Família cobriam $54 \%$ do total dos municípios brasileiros (Gazeta Mercantil, 07.ago.2000).

Por fim, em agosto de 2000, Serra passou a agir também no sentido de modificar as regras para a doação de órgãos, propondo a revogação da lei estabelecida em 1998. Segundo sua análise, a lei, ao tornar obrigatória a inscrição da condição de doador ou não-doador nos documentos de identidade, produziu muitas recusas, resultando em restrições e prejuízos para os pacientes que dependiam dos transplantes. A proposta do Ministro foi de simplificar o processo de consulta, passando a decisão para o âmbito da família ( $O$ Globo, 17.ago.2000).

Fazendo um balanço do Ministério da Saúde sob a gestão Serra até o momento (1998-2000), é incontestável o peso político que passou a caracterizar o órgão, independentemente de uma ou outra questão não poder ser ainda efetivamente contabilizada como uma demonstração de força diante 
do mercado - como é o caso, no meu entendimento, dos embates com a indústria farmacêutica. As maiores vitórias do Ministro Serra foram a aprovação do "PEC da saúde" e a regulamentação dos planos e seguros privados. Mas esse segundo ponto deve merecer maior reflexão, já que, além de ser uma medida voltada principalmente para a classe média, mesmo após a criação da ANS os planos de saúde continuaram apresentando diversos problemas, tais como a não-remuneração dos médicos credenciados e a prática de aumentos de preços muito acima da inflação (93\% em média, entre junho de 1998 e agosto de 2000, contra uma inflação de $16 \%$ no período). Esses fatos fizeram que entidades de defesa do consumidor, como o PROCON e o IDEC, passassem a defender, em agosto de 2000, a instalação no Congresso de uma CPI para os planos de saúde (Jornal do Brasil, 29.ago.2000; 31.ago.2000).

\section{CONSIDERAÇÕES FINAIS: O LUGAR DA SAÚDE PÚBLICA NAS POLÍTICAS SO- CIAIS DO GOVERNO FERNANDO HENRI- QUE CARDOSO (1995-2000)}

Uma constatação inequívoca na análise do governo Fernando Henrique Cardoso é que a sua agenda política é determinada pelo diagnóstico das crises econômicas internacionais, frente às quais surge a necessidade urgente de políticas de ajuste. Assim, obedece-se a uma lógica circular, na qual as decisões políticas governamentais, invariavelmente, apontam as reformas como vitais para a manutenção da estabilidade macroeconômica, que se coloca como o objetivo último da agenda de governo ou como uma espécie de sombra que acompanha todas as suas decisões. Nas palavras de Bresser Pereira (1997), um dos mentores intelectuais do governo, "a curto prazo, a reforma do Estado tenciona reduzir a dimensão do Estado e permitir o ajuste fiscal" (Bresser Pereira apud DINIZ, 2000, p. 53). É evidente que essa perspectiva demarca as políticas sociais, que ficam, portanto, numa posição secundária, até marginal, em relação à política macroeconômica.

A priorização do ajuste fiscal tem claramente contribuído para o aumento da pobreza e da desigualdade social no Brasil, como denunciaram as organizações não-governamentais (ONGs), reunidas em Genebra, em junho de 2000, durante a Assembléia Geral da ONU. Antes do encontro, em abril, uma ONG brasileira sediada em Brasília, o Instituto de Estudos Sócio-econômicos
(INESC), a partir de dados pesquisados pelo IPEA, denunciou que o número de pobres (aqueles que apresentam renda mensal abaixo de $\mathrm{R} \$ 149,00$ ) atingiu a maioria da população $(50,2 \%)$ e que o número de miseráveis (com renda mensal abaixo de $\mathrm{R} \$ 73,00)$ era estimado em torno de $28 \%$.

Esses números seriam uma conseqüência direta do pequeno investimento em programas sociais efetuado pelo governo Fernando Henrique Cardoso. Segundo o INESC, do total previsto no Orçamento Geral da União de 1999 (R \$9,05 bilhões), foram gastos apenas $\mathrm{R} \$ 3,68$ bilhões $(40,67 \%)$. Já as despesas com juros e encargos da dívida pública foram 11,37 vezes maiores. Já no ano 2000 (até o dia 22 de junho), os investimentos do governo federal foram de $\mathrm{R} \$ 419,5$ milhões, correspondendo a apenas 3\% do total de $\mathrm{R} \$ 12,5$ bilhões, previsto no Orçamento Geral da União (Jornal do Brasil, 16.abr.2000; Folha de S. Paulo, 25.jun.2000; Jornal do Brasil, 03.jul.2000).

Uma das principais conseqüências do caráter determinante da política econômica, indutora da recessão, é o aumento das taxas de desemprego formal e a diminuição dos padrões mínimos de proteção social no Brasil nas últimas décadas. A situação agrava-se com a opção pela abertura da economia ao capital estrangeiro e com a possibilidade de investimentos diretos serem atraídos a partir da redução do chamado custo Brasil - a tradução neoliberal para a regulamentação "excessiva" das relações entre o capital e o trabalho.

Assim, como afirma Cohn, o "novo padrão de regulação social não [se dá] mais via trabalho, mas via renda" (COHN, 2000, p. 185), de que é exemplo a reforma da Previdência Social, que “[...] após ter sido alçada ao estatuto de seguridade social em 1988, retrocede por iniciativa do governo à concepção de seguro social, uma vez que passa a vincular o acesso diferenciado ao valor dos benefícios segundo a capacidade de poupança individual de cada um durante sua vida útil" (ibidem; sem grifos no original).

Pode-se afirmar, portanto, que a flexibilização dos direitos dos trabalhadores, antes alocados de maneira segmentada pela cidadania regulada, deu lugar não a direitos universais, mas a uma outra forma de segmentação, mais excludente porque determinada pelo nível de renda.

Configura-se assim um sistema dual de proteção social (COHN, 2000, p. 186): de um lado, 
um subsistema contributivo, relativo aos benefícios sociais securitários; outro, redistributivo, relativo aos benefícios sociais assistenciais. É neste segundo subsistema, que seria financiado com os recursos do orçamento da União, que se encaixam as políticas sociais direcionadas para a saúde pública ${ }^{9}$.

Esse é o diagnóstico que se pode fazer quando se reflete sobre as políticas do governo Cardoso voltadas para a área da saúde. A questão da focalização aparece claramente no momento em que se delibera pela segmentação da assistência médico-hospitalar: às instituições públicas de saúde, sob responsabilidade do SUS, cabe o atendimento à população mais pobre; ao segmento privado, sob a denominação de saúde suplementar, fica o atendimento daqueles que têm uma renda que possibilite o pagamento desses serviços.

Cabe aqui uma observação a respeito da clientela dos planos e saúde privados. De acordo com a empresa de consultoria Target, que efetuou pesquisa sobre o potencial de consumo das cidades, regiões e classes sociais no país, os estimados 40 milhões de usuários da assistência médica suplementar não são apenas aqueles que possuem um alto nível de renda, mas também aqueles que pertencem à classe C. Fazem parte, portanto, de uma população estimada, em 1999, em cerca de 50,4 milhões de pessoas $(31,1 \%$ da população brasileira), que, "expulsos" compulsoriamente do sistema público de saúde, são obrigados a recorrer aos planos de saúde privados, com gastos totais da ordem de US $\$ 3,5$ bilhões (LEITÃO, 1999).

Essa mesma pesquisa avaliou os gastos com medicamentos, constatando que a classe $\mathrm{C}$ foi a que apresentou os maiores gastos com remédios em 1999 (em torno de US\$3,7 bilhões). Três anos antes, em 1996, esses gastos já eram muito altos (US\$3,2 bilhões), apesar do aumento da população considerada nessa faixa de consumo. A Tabela 7 ajuda a entender melhor esses indicadores:

TABELA 7 - Consumo da classe C, no Brasil, em 1996 e 1999

\begin{tabular}{|c|c|c|}
\hline Indicador & 1996 & 1999 \\
\hline Porcentagem da população & $26,3 \%$ & $31,1 \%$ \\
\hline Quantidade de pessoas & 41,3 milhões & 50,4 milhões \\
\hline Consumo total & US $\$ 97$ bilhões & US $\$ 99,2$ bilhões \\
\hline Gasto com medicamentos & US $\$ 3,2$ bilhões & US $\$ 3,7$ bilhões \\
\hline Outras despesas de saúde & US $\$ 2,5$ bilhões & US $\$ 3,5$ bilhões \\
\hline
\end{tabular}

Fonte: Leitão (1999).

Há que se admitir que a população em geral só tem a ganhar com a presença de um Ministro "forte" numa área como a saúde. Mas há que se perceber também até onde as ações concretas nessa área serão produzidas com resultados

9 “[...] Deve-se registrar que, no caso dos direitos não contributivos, o potencial redistributivo das políticas a ele vinculadas, na sua essência, é maior se e sempre quando se tratarem de políticas universais e financiadas com recursos orçamentários provenientes da contribuição fiscal. No caso brasileiro, no entanto, não é isso que vem se verificando: essas políticas, exatamente por se contraporem mais diretamente aos ditames da lógica macroeconômica em vigor de diminuição do déficit público, acabam por ter seus recursos cortados, e em conseqüência sua população-alvo restringida aos segmentos mais pobres da sociedade. É a conhecida focalização das políticas sociais, que se traduz, como testemunha nossa larga experiência histórica, em políticas de cunho clientelista, de caráter imediatista e, portanto, em políticas de governos e não em políticas de Estado" (COHN, 2000, p. 186). "cosméticos" e totalmente ineficazes, porque não vão até a raiz dos problemas sociais - como é o caso das políticas relacionadas aos programas do "Comunidade Solidária" - ou como um efeito de marketing político, visando a resultados eleitorais - como parece ser a ameaça de congelamento de preços que foi desferida pelo governo contra a indústria farmacêutica em 2000. São questões que somente o tempo poderá responder.

A resposta a ser dada pelo governo diante de grande parte dos problemas apontados acima talvez deixe claro se houve alguma mudança mais profunda, determinando a área da saúde como alvo prioritário das políticas públicas. Nesse sentido, a questão que permeia essa discussão diz respeito ao modelo econômico imposto ao país, como atesta a avaliação do sanitarista Paulo Buss, da Escola Nacional de Saúde Pública: "Cada meio ponto percentual de juros que pagamos sobre a dívida externa e interna pode representar até dois 
meses de ressarcimento integral do atendimento do Sistema Único de Saúde" (Jornal do Brasil, 22.jun.2000).

Para finalizar, uma palavra sobre a questão do impacto da descentralização do SUS. A história recente da Nova República tem demonstrado que as experiências inovadoras em termos de políticas sociais, inclusive na área da saúde, são aquelas promovidas por administrações municipais que têm como princípio político a participação da população local nas decisões, principalmente de caráter orçamentário. Essa prática traduz-se, por sua vez, em um exercício político-pedagógico de construção da democracia, atuando-se com transparência na administração da coisa pública (LESBAUPIN, 2000). Portanto, entendo que seria um retrocesso a conformação de políticas de caráter mais centralizado, que tenham como objetivo o uso clientelístico das verbas por parte do governo federal. A possibilidade de distorções e do mau uso dos recursos, que poderiam ser atribuídos à gestão local, dada a cultura política disseminada em torno do clientelismo e a ausência de participação em geral, deve ser relativizada em função da maior proximidade dos eleitores daqueles que executam as políticas públicas no seu município. O aumento dos níveis de escolaridade da população deve ser acompanhado pela educação para a cidadania e, conseqüentemente, devem ser criadas condições para qualificar a participação e o acesso às informações necessárias para a tomada de decisões em âmbito local, seguida do devido acompanhamento sobre a utilização das verbas na consecução das políticas públicas, entre elas a saúde.

Recebido em 30 de outubro de 2001. Aprovado em 2 de abril de 2002.

Ricardo Cesar Rocha da Costa (rcesarcosta@uol.com.br) é Mestre em Ciência Política pela Universidade Federal Fluminense (UFF).

\section{REFERÊNCIAS BIBLIOGRÁFICAS}

ABRANCHES, S. H. 1985. Os despossuídos : crescimento e pobreza no país do milagre. Rio de Janeiro : Jorge Zahar.

AKIN, J. S.; BIRDSALL, N. \& DE FERRANTI, D. 1987. Financing Health Services in Developing Countries. An Agenda for Reform : a World Bank Policy Study. Washington : The World Bank Group.

ALMEIDA, C. M. 1999. Reforma do Estado e reforma de sistemas de saúde. Ciência \& saúde coletiva, São Paulo, v. 4, n. 2, p. 263286, maio.

ARRETCHE, M. T. S. 1998. O processo de descentralização das políticas sociais no Brasil e seus determinantes. Campinas. Tese (Doutorado em Ciências Sociais). Instituto de Filosofia e Ciências Humanas, Universidade Estadual de Campinas.

BRAGA, J. C. \& GÓES DE PAULA, S. 1986. Saúde e previdência. Estudos de política social. São Paulo : Hucitec.

BRESSER PEREIRA, L. C. 1997. Managerial Reform in Brazil's Public Administration. Pa- per presented at the XVII World Congress of the International Political Science Association, occurred on Seoul, South Korea. Digit.

BUSS, P. M. 1995. Saúde e desigualdade : o caso do Brasil. In : BUSS, P. M. \& LABRA, M. E. (orgs.). Sistemas de saúde : continuidades e mudanças. São Paulo : Hucitec.

CALMON, P. P. 1999. A política orçamentária no primeiro governo Fernando Henrique Cardoso. In : ROCHA, P. E. (org.). Políticas públicas sociais. Brasília : Instituto Nacional de Estudos Sócio-Econômicos.

COHN, A. 1989. Caminhos da reforma sanitária. Lua Nova, São Paulo, n. 19, p. 123-140, nov.

1999. As políticas sociais no governo FHC. Tempo Social, São Paulo, v. 11, n. 2, p. 183197, out.

CORDEIRO, H. 1984. As empresas médicas : as transformações capitalistas da prática médica. Rio de Janeiro : Graal.

1991. Sistema Único de Saúde. Rio de Janeiro : Ayuri/Abrasco. 
COSTA, N. R. 1996. Inovação política, distributivismo e crise : a política de saúde nos anos 80 e 90. Dados, Rio de Janeiro, v. 39, n. 3, p. 479-511, set.-dez.

COSTA, R. C. R. 2000. Dilemas da reforma da saúde no Brasil frente à globalização financeira : implementando a descentralização do sistema público e a regulação do sistema privado de saúde. Niterói. Dissertação (Mestrado em Ciência Política). Instituto de Ciências Humanas e Filosofia, Universidade Federal Fluminense.

DINIZ, E. 2000. Globalização, reformas econômicas e elites empresariais : Brasil anos 1990. Rio de Janeiro : Fundação Getúlio Vargas.

ELIAS, P. E. 1997. Reforma ou contra-reforma na proteção social à saúde. Lua Nova, São Paulo, n. 40-41, p. 193-215.

ESCOREL, S. 1998. Reviravolta na saúde : origem e articulação do Movimento Sanitário. Rio de Janeiro : Fundação Instituto Oswaldo Cruz.

EVANS, P. 1982. A tríplice aliança: as multinacionais, as estatais e o capital nacional no desenvolvimento dependente brasileiro. Rio de Janeiro : Zahar.

FAVERET FILHO, P. \& OLIVEIRA, P. J. 1990. A universalização excludente : reflexões sobre as tendências do sistema de saúde. Dados, Rio de Janeiro, v. 33, n. 2, p. 257-283, maio-ago.

GERSCHMAN, S. 1995. A democracia inconclusa : um estudo da reforma sanitária brasileira. Rio de Janeiro : Fundação Instituto Oswaldo Cruz.

GIOVANELLA, L. \& FLEURY, S. 1996. Universalidade da atenção à saúde : acesso como categoria de análise. In : EIBENSCHUTZ, C. (org.). Política de saúde : o público e o privado. Rio de Janeiro : Fundação Instituto Oswaldo Cruz.

LESBAUPIN, I. 2000. Poder local x exclusão social : a experiência das prefeituras democráticas no Brasil. Petrópolis : Vozes.

LEWIS, M. \& MEDICI, A. 1998. Health Care Reform in Brazil. In : CRUZ-SACO, M. A. \& MESA-LAGO, C. (ed.). Do Options Exist? The Reform of Pension and Health Care Systems in Latin America. Pittsburgh : University of Pittsburgh Press.
MALLOY, J. M. 1986. A política da Previdência Social no Brasil. Rio de Janeiro : Graal.

MEDICI, A. C. \& OLIVEIRA, F. E. B. 1992. Considerações sobre o sucateamento das redes pública e privada de saúde. Texto para discussão n. 267. Rio de Janeiro : Instituto de Pesquisas Econômicas Aplicadas.

MEDICI, A. C. 1995. Saúde : modelos de gestão descentralizada. Alternativas para o Brasil. In : VELLOSO, J. P. R., ALBUQUERQUE, R. C. \& KNOOP, J. (coords.). Políticas sociais no Brasil : descentralização, eficiência e eqüidade. Rio de Janeiro : Instituto Nacional de Altos Estudos-Instituto Latino-Americano de Desenvolvimento Econômico e Social.

MELO, M. A. B. C. 1993. Anatomia do fracasso : intermediação de interesses e a reforma das políticas sociais na Nova República. Dados, Rio de Janeiro, v. 36, n. 1, p. 119-163, jan.abr.

REIS, C. O. O., RIBEIRO, J. A. C. \& PIOLA, S. F. 2001. Financiamento das políticas sociais nos anos 1990 : o caso do Ministério da Saúde. Texto para discussão n. 802. Rio de Janeiro : Instituto de Pesquisas Econômicas Aplicadas.

OLIVA-AUGUSTO, M. H. \& COSTA, O. V. 2000. Entre o público e o privado : a saúde hoje no Brasil. Tempo Social, São Paulo, v. 11, n. 2, p. 199-217, fev.

PEREIRA, C. 1996. A política pública como caixa de Pandora : organização de interesses, processo decisório e efeitos perversos na reforma sanitária brasileira - 1985-1989. Dados, Rio de Janeiro, v. 39, n. 3, p. 423-477, set.-dez.

POSSAS, C. A. 1995. A articulação público-privado e o cuidado com a saúde dos pobres : implicações das políticas de ajuste estrutural na América Latina. In : EIBENSCHUTZ, C. (org.). Política de saúde : o público e o privado. Rio de Janeiro : Fundação Instituto Oswaldo Cruz.

ROCHA, P. E. (org.). 1999. Políticas públicas sociais : um novo olhar sobre o orçamento da União. Brasília : Instituto Nacional de Estudos Sócio-Econômicos.

SANTOS, W. G. 1994. Cidadania e justiça : a política social na ordem brasileira. Rio de 
Janeiro : Campus.

SILVA, A. A. 1997. A predação do social. Niterói : UFF.

SOARES, L. T. R. 1999. Ajuste neoliberal e desajuste social na América Latina. Rio de Janeiro : UFRJ.

TEIXEIRA, A. 1995. Em defesa da seguridade e da Constituição de 88. Monitor público, Rio de Janeiro, ano 2, n. 6, p. 15-17, jun.-ago.

TELAROLLI JR., R. 1996. Poder e saúde : as epidemias e a formação dos serviços de saúde em São Paulo. São Paulo : Universidade Estadual Paulista.

WORLD BANK. 1982. Brazilian Health Care Financing and Health Policy: An International Perspective. Washington : The World Bank.

\section{OUTRAS FONTES}

COSTA, N. R.; RIBEIRO, J. M.; SILVA, P. L. B. \& MELO, M. A. B. C. 2000. Análise comparada do regime regulatório na infraestrutura e no setor saúde. Nota técnica n. 4. Brasília : Agência Nacional de Saúde Suplementar.

DUPAS, G. 1998. O hálito fétido da saúde brasileira. O Estado de S. Paulo, 01.ago.

Folha de S. Paulo, 1995-2000.

FRANCO, G. H. B. 2000. Vinculações. Jornal do Brasil, Rio de Janeiro, caderno "Economia", p. 4, 13.ago.

GASPARI, E. 1997. O dedo da saúde. Folha de S. Paulo, p. A-7, 28.maio.

Gazeta Mercantil, 1997-2000.

JATENE, A. 1997. Onde foi parar o dinheiro da saúde? Veja, São Paulo, p. 108, 22.out.
Jornal do Brasil, 1997-2000.

LEITÃO, M. 1999. "Plano de mudanças". O Globo, Rio de Janeiro, p. 30, 14.nov.

O Estado de S. Paulo, 1998-2000.

O Globo, 1997-2000.

OPAS-OMS. 1998. A saúde no Brasil. Brasília : Organização Pan-Americana de SaúdeOrganização Mundial de Saúde.

PNUD. 1996. Relatório sobre o desenvolvimento humano no Brasil. Brasília : Programa das Nações Unidas para o DesenvolvimentoInstituto de Pesquisas Econômicas Aplicadas.

SERRA, J. 1999. Controle sobre planos de saúde. Jornal do Brasil, Rio de Janeiro, p. 10, 21 .nov. 2000. Saúde : a vinculação necessária. Folha de S. Paulo, p. A-3, 09.jul.

Valor Econômico, 2000. 